\title{
Estimation and Prediction of Riverbank Erosion Susceptibility and Shifting Rate Using DSAS, BEHI, and REBVI Models: Evidence from the Lower Ganga River in India
}

Md. Hasanuzzaman

Raja Narendra Lal Khan Women's College

\section{Biswajit Bera}

Sidho-Kanho-Birsha University

Aznarul Islam

Aliah University

Pravat Kumar Shit ( $D$ pravatgeo2007@gmail.com )

Raja N.L.Khan Women's College under Vidyasagar University https://orcid.org/0000-0001-5834-0495

\section{Research Article}

Keywords: Erosion-accretion, DSAS model, BEHI, REBVI, Alluvial channel, remote sensing

Posted Date: December 15th, 2021

DOI: https://doi.org/10.21203/rs.3.rs-1097959/v1

License: (c) (i) This work is licensed under a Creative Commons Attribution 4.0 International License.

Read Full License 
Estimation and prediction of riverbank erosion susceptibility and shifting rate using DSAS, BEHI, and REBVI models: Evidence from the lower Ganga River in India

Md. Hasanuzzaman ${ }^{1}$; Biswajit Bera ${ }^{2}$ Aznarul Islam ${ }^{3}$ and Pravat Kumar Shit ${ }^{1 *}$

4

$5 \quad{ }^{1}$ PG Department of Geography, Raja N. L. Khan Women's College (Autonomous), Gope Palace,

6 Midnapore-721102, West Bengal, India

7

8 2Department of Geography, Sidho Kanho Birsha University, Puruliya, West Bengal, India

9 3Department of Geography, Aliah University, Kolkata, India

Md. Hasanuzzaman

14 Email: hasan20geo@gmail.com

15 Biswajit Bera

16

Email: biswajitbera007@gmail.com

17 Aznarul Islam

18

Email: aznarul.geog@aliah.ac.in

19

20

Pravat Kumar Shit

21 Email: pravatgeo2007@gmail.com

22

23

*Corresponding author: email: pravatgeo2007@gmail.com (Pravat Kumar Shit)

24

25

26

27

28

29 
Abstract

31 The process of riverbank erosion (RE) is often accelerated by natural events and anthropogenic activities

32 leading to the transformation of this natural process to natural hazard. The present study aims to estimate

33 bank erosion rate and prediction of the lower Ganga River in India using digital shoreline analysis system

34 (DSAS) model. The prediction of RE susceptibility mapping has been generated using three ensemble

35 models such as DSAS, bank erosion hazard index (BEHI), and river embankment breaching vulnerability

36 index (REBVI). For the study satellite images and field data (bank materials, geotechnical parameters,

37 embankment structure, hydraulic pressure etc.) have been used to recognize the river bank position and

38 BEHI and REBVI scores. During 1973-2020, the average bank erosion and accretion rate was found

$390.059 \mathrm{~km} / \mathrm{y}$ and $0.022 \mathrm{~km} / \mathrm{y}$ at the left bank while $0.026 \mathrm{~km} / \mathrm{y}$ and 0.046 at the right bank respectively.

40 The prediction results illustrated that the very high vulnerable condition of 06 villages and 21 villages for

41 high vulnerable due to left bank erosion. BEHI and REBVI scores have been the significant performance

42 of understanding and identification of RE vulnerable areas. The long-term (2020-2045) average erosion

43 and deposition rate was predicted at $0.135 \mathrm{~km} / \mathrm{y}$ and $0.024 \mathrm{~km} / \mathrm{y}$ at the left bank and $0.043 \mathrm{~km} / \mathrm{y}$ and

$440.045 \mathrm{~km} / \mathrm{y}$ at the right bank respectively. The prediction accuracy and validation of models were

45 measures by statistical techniques such as student's t-test, RMSE, and $\mathrm{R}^{2}$ values. This study would be

46 help planners and decision makers the spatial guidelines to understanding future trends of bank erosion

47 and shifting rate for land-use planning and management strategies to protect riverbank.

Keywords: Erosion-accretion; DSAS model; BEHI; REBVI; Alluvial channel; remote sensing

51

52

53

54

55

56

57

58

59

60 


\section{Introduction}

The Ganga River is the second largest river in terms of sediment transport in the world (Chakrapani et al., 1995), which is covering 1.09 million $\mathrm{km}^{2}$ basin areas (Dewan et al., 2017). This river has flowed through different types of landforms and when the passes through the deltaic region the river adjusts itself very dynamically by the erosion- accretion (Mondal \& Satpati, 2012). The Farakka barrage has been constructed in 1975 across the Ganga River in between the Malda and Murshidabad districts of West Bengal in India. The main object of the construction of the Farakka barrage has to divert water to the Bhagirathi-Hooghly River for the rejuvenation of Dr. Syama Prasad Mookerjee Port (erstwhile Kolkata port) and to provide saline free water to the urban areas of Kolkata (Islam and Guchhait, 2017). It made important changes in the hydrological, morphological, patterns and sedimentological characteristics of the Ganga River (Rudra, 2010; Bera et al, 2019). However, due to this construction, few major problems such as bank erosion, riverbank collapse, the formation of bars, and subsequent bank failure have been evidenced and lateral shifting or avulsion are being frequently occurred within this region (Guchhait et al, 2016). The river derived high discharge and huge sediment during monsoon season, and after construction of the Farakka barrage, backwater overtops of the banks and inundates floodplain especially in monsoon season (Rudra 2010). Thousands of people are being affected by this natural disaster almost every year (Thakur et al., 2011).

Therefore, many researchers have been work in this region by using various method and techniques (Table 1). However, most of the previous studies on the Ganga River have carried out the traditional or manual overlapping method for the determination of erosion-accretion (EA) calculation. Therefore, the present study statistical-based the digital shoreline analysis system (DSAS) automated model used the estimation and prediction of riverbank erosion-accretion and bankline shifting (BS).

\section{Table 1 Previous literatures of the study area}

At present, earth observatory techniques RS and GIS have performed a significant role for change detection and mapping in river systems including buffer zone dynamics at a different strategic scale (Wang and $\mathrm{Xu}, 2018$ ). The RS and GIS platforms with field verification can accurately done and quickly investigate the river morphological changes (Langat et al., 2018). GIS-based spatial analysis, both the linear (here river bank) and areal attributes (here floodplain area) of the study area have been considered for assessing the temporal trends. The demarcation and comparison of river bankline from toposheet, aerial photographs, and satellite imageries are a very common process. But, the mathematical, scientific, automated, and software-based models are not found for calculation and prediction of river bankline erosion-accretion using historical trend data. Several models are present in the field of shoreline shifting such as digital shoreline analysis system (DSAS).Therefore, DSAS is a highly acceptable method which was developed by the United States Geological Survey (USGS) and capable to accurately measure the 
rate and predication of different river bank line positions (right and left bank separately) (Thieler et al. 2009; Ashraf and Shakir, 2018; Jana, 2019). Many researcher have been successfully applied the DSAS model in their field such as Hapke et al. (2009) in USA, Hai-Hoa et al. (2013) in Vietnam, Esteves et al. (2009) in UK, Kuleli et al. (2011) in Turkey, Alberico et al. (2012) in Italy, Ellison and Zouh (2012) in Cameroon, Appeaning Addo et al. (2008) in Ghana, Natesan et al. (2013), Mukhopadhyay et al. (2012) in India, Rahman et al. (2011) in India and Bangladesh etc. Generally, the DSAS model is used in the context particularly for the sea shoreline migration. However, in this study, the right and the left bank can be separately mapped with a higher degree of accuracy. Especially, efforts are made to measure mouza (village) wise EA within the left bank buffer zone of River Ganga.

Therefore, this work has dealt with a novel GIS technique in the field of river bankline migration to measure the EA rate and it also provides a predicted database of lateral migration trends. In the previous researches, different methods had been applied to present erosion and accretion, but the computation of eroded and accreted areas are not clearly quantified as the specified administrative unit and future prediction. It is a big research gap in the study area. Therefore, the EA rate has been calculated and future predicted in a systematic manner for corresponding administrative areas (Mouza) and both bankline in the present study area. Also, this work has been calculated the bank erosion hazard index (BEHI) and river embankment breaching vulnerability index (REBVI) for a clear understanding of the study area EA nature.

\section{Study area}

The Ganga River is one of the largest rivers in India. This study, we attempted the lower Gangetic flood region. The Ganga River after enters West Bengal suddenly which gets confined on both sides because the left bank (Malda) is surrounded through the Diara region and the right bank is surrounded by the outliers of the Rajmahal hills. The Diara region is an alluvial deposition area between the upland and the marshy Tal track. According to the Geological Survey of India, along the left bank, there is the MaldaKishanganj Fault while along the right bank the Rajmahal Fault exists. Those faults have forced the Ganga River of the study area to flow in a relatively narrow valley (Sinha and Ghosh, 2012). During the monsoon, the Ganga River water level is cross the danger or the extreme danger level. According to the Central Water Commission of India, the average annual sediment load is 200.53 (Mt) at the Farakka (Khan et al., 2018).

Geographical extended between $24^{\circ} 39^{\prime} 38^{\prime \prime} \mathrm{N}$ to $25^{\circ} 13^{\prime} 16^{\prime \prime} \mathrm{N}$ and $87^{\circ} 46^{\prime} 25^{\prime \prime}$ E to $88^{\circ} 00^{\prime} 16^{\prime \prime}$ E with covering the distance of $8.7 \mathrm{~km}$ (Fig. 1). This portion of the river is very dynamic channel behavior. People are facing every year with natural hazards due to shifting of the river channel, seasonal submergence of char land (channel bar) and flooding, etc. The Planning Commission (1996) reported that around 4.5 lakh of people had lost their homes in 40 village panchayats (the village administration system 
in India) of Malda district, India (Dutta, 2011). In this study, transect-wise EA and prediction have been estimated along both the banks, however, mouza (village) wise EA and prediction have been calculated for only the left bank or the most affected mouzas of the Malda district. The present study has identified 100 mouzas (smallest administrative unit for revenue collection) along the left bank of the Ganga River in Malda district (Fig. 1). These 100 villages are distributed in 4 blocks i.e., Manikchak block (39 village), English Bazar (11 village), Kaliachak-I (23 village), and Kaliachak-III (27 village) (Table S1).

Fig. 1. Location map of the study area (A) India, (B) West Bengal, (C) The Ganga River floodplain with river buffer Mouza.

\section{Data used}

In the research MSS, TM, ETM+ and OLI datasets used in the year of 1973, 1987, 1997, 2007 and 2020 to demarcate the channel banklines (Table 2). All the satellite images were projected in the UTM projection with zone 45 north and WGS84 datum and resample in the ArcGIS environment. To maintain the data quality, all the images have been co-registered using the first-order polynomial model with the accuracy of root mean square error (RMSE) of less than 0.5 pixels with a minimum number of ground control points (GCPs). We have measured 29 sampling sites of bank height, bank full discharge height, vegetation root depth, root density, surface protection, bank angle, soil texture, base width, bank slope, and water height during the field survey (2019-2020) for BEHI and REBVI models. The work has been carried out as per the following methodology (Fig. 2).

Table 2 Data type used for different purposes and respective sources.

Fig. 2. Conceptual framework of the methods used.

\subsection{Bank lines extraction}

We have used the normalized difference water index (NDWI) and modified normalized difference water index (MNDWI) for bank line extraction based on Eq. 1 and 2.

$$
\text { NDWI }=\text { Green }- \text { NIR/Green }+ \text { NIR }
$$

To estimate the MNDWI, the MIR band of Landsat 7, SWIR band of Landsat 5 and 8 along the green band are also used. The technique for calculating the MNDWI has given by $\mathrm{Xu}$ (2006) as:

$$
\begin{aligned}
& \text { MNDWI }=\text { Green }- \text { MIR } / \text { Green }+ \text { MIR } \\
& M N D W I=\text { Green }- \text { SWIR } / \text { Green }+ \text { SWIR }
\end{aligned}
$$

The NDWI and MNDWI final images are used for digitizing the bankline position (right and left banklines separately) by ArcGIS software (de Bethune et al., 1998, Jana, 2019).

\subsection{Estimation of erosion-accretion (EA) rate and its prediction}


In the present work, the DSAS extension tool of ArcGIS has been used to assess the rate of EA of the bank lines. Subsequently, their predictions have also estimated by using the reference extracted baselines and auto-generated transects. For the DSAS based statistical output, two further models have been employed like, End Point Rate (EPR) model for computing present EA of the bank lines or shifting rate and Linear Regression (LRR) model to estimate the shifting of future bank lines.

\subsubsection{EPR model for calculating the bankline erosion-accretion rate}

The rate of change in the position of banklines is frequently applied to summarize the historical bankline shifting and their future prediction. The model is based on the assumption that the observed periodical rate of change of bankline position is the best estimate for prediction of the future bankline (Fenster et al., 1993) and no prior knowledge regarding the flow discharge or sediment transport is required because the cumulative effect of all the underlined processes is assumed to be captured in the position history (Li et al., 2001).

In the EPR model, based on the availability of data, studied time period is divided into four temporal datasets i.e., 1973 to 1987, 1987 to 1997, 1997 to 2007, and 2007 to 2020 (Fig. 3). For each dataset, superimposed technique has been portrayed to demarcate bank line positions and achieved a final line of overlapping visualization and this line is find out as a superimpose line. Afterward, a buffer of $100 \mathrm{~m}$ distance from the superimpose line is used to drawn towards the right for the right bank and left for the left bank to demarcate the baselines. Therefore, transects have been placed at a $50 \mathrm{~m}$ gap on the baseline. These transects are created at the acute angle to the baseline up to $15 \mathrm{~km}$ distance away from both banks. These transects are auto-generated with $\pm 0.5 \mathrm{~m}$ uncertainties depending on the orientation of the baselines. Moreover, around 1347 transects on the left banks and 1456 on the right bank are placed along the baseline with $50 \mathrm{~m}$ spacing to cover the entire selected tracts (about $8.7 \mathrm{~km}$ ) (Fig. 3).

$$
E P R=\frac{\text { Distance of bankline movement }}{\text { Time between earlier and recent }}(\text { Eq. 4) }
$$

In EPR model, previous and recent data of two banklines are needed for this calculation and do not require any earlier knowledge regarding the hydraulic interference or sediment transport. Moreover, the model uses data of two years at a single time. For example, the model calculates the EA between 1973 to 1987 based on the change, detected between the period 1973 to 1987 . Thereafter, 1987 to 1997 then 1997 to 2007 and finally 2007 to 2020 to calculate the riverbank EA rates, which depict the shifting trend over periods.

Fig. 3. Different banklines (1973-2020) are positioned along the baseline. All transects are oriented at angle with the corresponding baselines. (A) Right bankline and (B) Lift bankline. 


$$
Y_{p b}=\left\{\beta_{E P R}\left(X_{e b}-X_{r b}\right)\right\}+Y_{r b}
$$

On the other hand, EPR intercept is calculated by Eq. 6.

$\alpha_{E P R}=Y_{e b}-\left\{\frac{Y_{e b}-Y_{r b}}{X_{r b}-X_{e b}}\right\} X_{e b}=Y_{r b}-\left\{\frac{Y_{e b}-Y_{r b}}{X_{r b}-X_{e b}}\right\} X_{r b}$

The rate of bankline migration for a given set of transects, the $\beta_{E P R}$ is calculated by the Eq.7

$$
\beta_{E P R}=\left\{\frac{Y_{e b}-Y_{r b}}{X_{r b}-X_{e b}}\right\}
$$

\subsubsection{LRR model for predicting the bankline erosion-accretion/shifting rate}

where, $\mathrm{X}$ is the time interval $\left(X_{e b}-X_{r b}\right)$ between earlier bankline $\left(X_{e b}\right)$ and recent bankline $\left(X_{r b}\right)$, $\alpha_{E P R}$ is model intercept, $\beta_{E P R}$ denotes the rate of riverbank shifting (slope or regression coefficient).

LRR model uses statistics of model generated baseline, which is demarcated by temporal period of bank line migration. It has shown bank position of the subsequent year of the selected time span. Therefore, the channel side position of the data set 2020 is considered as a common baseline to all sets. The result of this attempt has been scrutinized by the least-square method (fitting a regression line) to predict the channel shifting and bank line position (Thieler et al., 2009). For this a regression line is placed to all linear series, points along a user particular transect. Afterward the river bankline migration rate is estimated by fitting the least-square regression lines. It is process used to all river bankline for a practicular transect. Therefore, this method is used for predicting the position. The short-term (2025), intermediate-term (2035) and long-term (2045) basis with a period of 5 years, 15 years and 25 years, respectively are used for prediction in this study. Moreover, position of bank line of 2020 is predicted for accuracy assessment. Then the value of EPR is used to predict the future riverbank positions $\left(Y_{p b}\right)$. This is because of the predicted riverbank position $\left(X_{p b}\right)$ can extend beyond the recent riverbank (either at left or right). Hence, 


\subsection{Determination for village wise erosion-accretion area}

In this study, we have also compared the bank line position of the river concerning selected different data sets. After that, efforts have been made to measure erosion-accretion separately for each period at the left side of the channel. Riverbank lines of different periods have represented different mouza boundaries. Therefore, Village/Mouza wise EA has been manually calculated with the help of ArcGIS software.

\subsection{BEHI measurement}

BEHI is an important fluvial geomorphic tool for the analysis of the susceptibility of riverbank erosion (Rosgen 2006). The BEHI methodology evaluates the function of some erodibility variables including bank height, bankfull height, bank protection, bank combination, vegetation root depth, root density, and bank material stratification. As per the guidelines of Rosgen (2001 and 2006) (Table 3), BEHI score has been calculated. All collected primary data of 29 samples of the left bank (facing downstream) by the field survey have been used for BEHI score calculation (Simpson et al. 2014 and Ghosh et al. 2016) (SM $1)$.

Table 3: Guidelines for measuring complete BEHI (After, Rosgen, 2001).

\subsection{Calculation of REBVI}

We have measured 29 samples of riverbank properties for calculated of REBVI score (Mondal et al. 2012). Bank materials and geotechnical attributes (soil texture, bulk density, plasticity index, compressive strength, and safety factor), the geometry of embankment (bank top height, base width, and bank slope), and hydraulic pressure (water height) detailed observations of breach parameters have been investigated. The EB has been calculated to a multi-criteria approach for all of the input variables. We have utilized weighting systems based on the values from $0-4$, where, '4' means very highly vulnerable, ' 3 ' highly vulnerable, '2' moderately vulnerable, ' 1 ' less vulnerable, and ' 0 ' very less vulnerable. Therefore, based on their importance and stability of materials to the potential of embankments breaching each set of continuous data have ranks from $1-5$. The ranks assigned to different features of the individual themes are presented (Table S2). After deriving the normal weights and ranks, all individual parameters have been integrated in a linear model to determine REBVI using Eq. 10.

$$
R E B V I=\left(R_{S T} \times W_{S T}\right)+\left(R_{B D} \times W_{B D}\right)+\left(R_{S F} \times W_{S F}\right)+\left(R_{T H} \times W_{T H}\right)+\left(R_{B S} \times W_{B S}\right)\left(R_{W H} \times W_{W H}\right) \ldots \ldots \ldots \ldots(E q .10)
$$

Where, $\mathrm{R}=$ rank value, $\mathrm{W}=$ weight value, $\mathrm{ST}=$ Soil Texture, $\mathrm{BD}=$ Bulk Density, $\mathrm{SF}=$ Safety Factor, $\mathrm{TH}=$ Top Height, BW = Base Width of Embankment, BS= Bank Slope, WH= Water Height (SM2).

\subsection{Model validation methods}

DSAS model has been used for estimating the future riverbank EA, shifting and future bankline position. But before the future prediction, the model has to be validated with the current circumstances (Mukhopadhyay et al., 2012; Jana, 2019). Therefore, the LRR method is employed to predict future bank 
line position based on EPR (slope), interval, and intercept value. Based on this, the estimated bank line position of 2020 is calculated and the predicted bank line is verified with the actual bank line 2020. It is demarcated from the satellite image of 2020. The positional error estimated using RMSE. It is carried out using the Eq. 11.

$$
R M S E=\left[n^{-1} \sum_{i=0}^{n}\left(X_{m b}-X_{\mathrm{ab}}\right)^{2}+\left(Y_{m b}-Y_{\mathrm{ab}}\right)^{2}\right]^{1 / 2}
$$

where, $X_{m b}$ and $Y_{m b}$ are the model estimated bankline, and $X_{a b}$ and $Y_{a b}$ are the actual bankline in $X$ (time) and $Y$ (position) coordinates the sample points.

Potential errors associated with satellite maps (Datum changes, different surveying standards, projection errors, distortions from uneven shrinkage etc. (Anders and Byrnes, 1991). In the work, four type errors are identified for measuring the rate change and it may be of both positional and calculation related errors. Calculation Uncertainties are related to the skill and approach such as; pixel error $E_{p}$, digitizing error $E_{d}$, and rectification error $E_{r}$ and positional uncertainties are related to the features and phenomena that reduce the precision and accuracy of defining a bankline (both) position from a given data set such as; seasonal error $E_{s}$ (Kankara et al. 2015). Finally, total uncertainty value was estimated for each banklines by accounting both positional and measurement uncertainties as:

$$
E t= \pm \sqrt{E_{p}+E_{d}+E_{r}+E_{s}}
$$

The bankline positional error is also verified with 100 GCPs collected from the field survey during 20192020. Out of these, GCPs and 29 GCPs have been used for BEHI and REBVI calculation. The RMSE and t-test are adopted for the model validation of estimated banklines (left and right) which gives an accurate portrayal between actual and predicted banklines.

\section{Results}

\subsection{DSAS based riverbank erosion-accretion and future prediction assessment}

The DSAS model-based transect (T) wise riverbank erosion-accretion or shifting trend is illustrated in table 4 and figure 4 . The result from 1973 to 1987 depicts that the mean rate erosion rate is $0.129 \mathrm{~km} / \mathrm{y}$ at the left bank and $0.61 \mathrm{~km} / \mathrm{y}$ at the right bank. Among the transect 661 at the left bank and 548 at the right bank are erosion dominant transects. The EA rate and the number of the affected transect were indicated that the channel was very active through the erosion process of both sides of the banks. Therefore, the correspondence of high erosion at both banks was indicating channel widening.

Table 4 DSAS model based mean and stander deviation of erosion-accretion of both bank

Fig. 4. DSAS model-based prediction of riverbank erosion and deposition rate along transects during the different study periods, at the bothbanks. (a) Right bank and (b) Lift bank of 1973-1987; (c) Right bank 
and (d) Lift bank of 1987-1997; (e) Right bank and (f) Lift bank of 1997-2007; (g) Right bank and (h) Lift bank of 2007-2020; (i) Right bank and (j) Lift bank of 2000-2025; (k) Right bank and (l) Lift bank of 2025-2035; (m) Right bank and (n) Lift bank of 2035-2045.

During 2007-2020, the mean erosion of the left bank is $0.168 \mathrm{~km} / \mathrm{y}$, and erosion of the right bank is 0.079 $\mathrm{km} / \mathrm{y}$. Among the transect 455 at the left bank and 296 at the right bank are erosion dominant transects (Fig. 5). In this observation, the left bank experiences extensive erosion and disproportionate sediment accretion along the right bank. This result indicates a widening river course triggered by persistent erosion on both banks, as an overall result, the river channel shifts towards the left bank with a large extent of sedimentation at the right bank. Also, we observed that from 1973 to the present time bank erosion of left bank is concentrated pocket places from all over bankline. In recent times erosion of the left bank has consented lower part of the study area.

Fig. 5. DSAS model-based prediction of riverbank accretion-erosion rate during the study periods at the both banks. (a) Right bank and (b) Lift bank of 1973-1987; (c) Right bank and (d) Lift bank of 19871997; (e) Right bank and (f) Lift bank of 1997-2007; (g) Right bank and (h) Lift bank of 2007-2020; (i) Right bank and (j) Lift bank of 1973-2020; (k) Right bank and (1) Lift bank of 2020-2025; (m) Right bank and (n) Lift bank of 2025-2035; (o) Right bank and (p) Lift bank of 2035-2045.

The short-term prediction (2020 to 2025) of bankline mean erosion and accretion rate are estimated 0.089 $\mathrm{km} / \mathrm{y}$ and $0.032 \mathrm{~km} / \mathrm{y}$ at the left bank and $0.045 \mathrm{~km} / \mathrm{y}$ and $0.060 \mathrm{~km} / \mathrm{y}$ at the right bank respectively (Fig. 5). The medium-term prediction (2020 to 2035) of the average erosion and accretion rate are predicted $0.151 \mathrm{~km} / \mathrm{y}$ and $0.019 \mathrm{~km} / \mathrm{y}$ at the left bank and $0.043 \mathrm{~km} / \mathrm{y}$ and $0.026 \mathrm{~km} / \mathrm{y}$ at the right bank respectively. The long-term (2020 to 2045) bankline mean erosion and deposition rate are estimated at $0.164 \mathrm{~km} / \mathrm{y}$ and $0.021 \mathrm{~km} / \mathrm{y}$ at the left bank and $0.031 \mathrm{~km} / \mathrm{y}$ and $0.045 \mathrm{~km} / \mathrm{y}$ at the right bank respectively. This result revels that the erosion process is dominant to the left bank of BS through EA in the future (Fig. 6).

Fig. 6. Spatial pattern of bankline migration after prediction in the year 2020, 2025, 2035, and 2045 .

4.2 Village wise spatial distributions of erosion-accretion and future prediction analysis

Spatial distributions of erosion and accretion of 100 villages at buffer zone of the Ganga River (adjacent village areas of Malda district) during the period 1973-2045 (Fig. 7) have been minutely portrayed in this study. Overall results depict that the thirteen villages have experienced regular erosion but continues accretion have been experienced in the three villages during the entire study periods. From 1973 to the present time, the Palgachhi, Jagannathpur, Gadai, Narayanpur, Manikchak, and Gopalpur mouza become the most eroded or vulnerable villages. During the predicted period from 2020 to 2045, twenty-one villages will show active erosion in this vulnerable mouza in the future. 
Fig. 7. Mouza wise spatial distributions of erosion and deposition area during the period (a) 1973-1987, (b) 1987-1997, (c) 1997-2007, (d) 2007-2020, (e) 2020-2025, (f) 2025-2035, and (g) 2035-2-45.

\subsection{Model validation}

The Linear Regression Rate (LRR) is $2.4 \mathrm{~m} / \mathrm{y}$ (left bank) and $2.2 \mathrm{~m} / \mathrm{y}$ (right bank) for all transects. The band of confidence around the reported rate of change is $-2.6+/-0.78$. Therefore, it can be $88 \%$ confident that the true rate of change is between 3.21 to $1.79 \mathrm{~m} / \mathrm{yr}$. Also, $R^{2}$ ( 0.82 for the left bank and 0.79 for the right bank) value justifies the acceptance of the work. The RMSE at each transect point are placed by error vectors and the BS varies from 0.124 to 0.921 with an overall mean error of 0.363 (Table 5). The ttest results reveal that the model has a good prediction capacity $(\mathrm{p}<0.05)$. Therefore, this result is accurately matched with the predicted bankline position corresponding with the actual bankline position (Fig. 6).

Table 5 DSAS model-based results of RMSE and student's t-test

\subsection{BEHI assessment}

Based on the ratings of the above selected all variables of 29 samples considered for BEHI scores an Erosion Hazard value Map of the left bank has been prepared (Fig. 8). The results show that out of 29, fourteen sample segments are very high to extremely vulnerable to bank erosion hazard due to toe erosion caused due to helical flow. Thus, these mouzas have appeared as very dynamic erosional mouza in our study. On the other hand, 5 segments are low to very vulnerable to bank erosion hazard due to low slope, sedimentation, presence of riparian vegetation and engineering construction such as embankments, spur, etc. In this analysis, we have observed that in the upper part of the Farakka barrage, BEHI values are high to the extreme but at the lower stretchof the Farakka barrage, BEHI values are low to very low (Table S3). The values of bankfull height are very high in most of the bank segments of the upper part of the Farakka barrage because the water levels rise significantly during peak monsoon season.

Fig. 8. Sample Segment (location) specific mean BEHI ratings along the left bank of the Ganga River, (a) low BEHI score area (7.25) at Deonapur, (b) low BEHI score area (22.75) at Jagannathpur, (c) high BEHI score area (42.45) at Jot Bhabani, (d) high BEHI score area (43.95) at Gopalpur.

\subsection{REBVI assessment}

The REBVI outcome of above selected variable of 29 samples depicted that highest score is less potential for EB or riverbank erosion (Table 8). The distribution of the REBVI score is five-category such as Very High ( $<40$ is High potential to prevent EB and potential for slope stability), High (41-50) Medium (5160), Low (61-70), and very low (>70 is very high probability of EB due to bank failure, piping and 
overtopping). According to the REBVI score, Suzapur Mandai (S24) and Par Paranpara (S27) arethe potential to prevent EB and potential for slope stability. Gopalpur (S13) is a very high probability of EB due to bank failure, piping, and overtopping (Fig. 9). Also, nine sample segments are a high probability of EB (Table S4).

Fig. 9. Sample Segment (location) specific mean REBVI ratings along the left bank of the Ganga River, (a) during the bank erosion time at PalgachhiMouza, (b) during the bank erosion time at Dharampur, (c) during the bank erosion time at Manikchak, (d) during the bank erosion time at Gupalpur, (e) during the bank erosion time at Sukhesna, (f) Above $90^{\circ}$ angel slope at Panchanandapur, (g) Soil different layer at Bagdukra, (h) Temporary embankment at Nayagram, (i) broken embankment at Jot Ananta.

\section{Discussion and critical analysis}

In the study stretch of the Ganga River has been facing bank channel shifting and high bank EA almost every year and continuously changed its buffer areas with time. The present analysis shows that the study part of the Ganga River is very active for the erosion process at the left bank and is very active for the accretion process at the right bank. According to DSAS based prediction, the same results are being continued in the future. The Ganga River does not follow any particular pattern or trend of EA at both banks. A general observation from this whole research reflects that the most dynamic channel as expressed through frequent migration is located in the upper part of the Farakka barrage. The lower part of the barrage is relatively stable and sequential at the left bank. In the last 47-year, the Ganga River course displays a high dynamic adjustment for their need and this changed channel behaviour in a very dramatic and dangerous way. Therefore, this change should be assessed but the understanding process is very complex. However, this work has been done to provide a dataset of the village wise EA of the river Ganga for Malda district. In the study time, six villages are very vulnerable villages for severe erosion. Besides, twenty-one villages will be noted as highly vulnerable mouzas in the future. This study shows that channel shifting or migration through the erosion has dominated in the left bank over historical and future time periods. We observed from historical, present, and future database erosion has consented to the different pockets of both bankline. Also, BEHI and REBVI values provide the understanding of the nature of embankment and bank material an important role for developed erosion pocket.

Fig. 10. River Flow Characteristics during the Monsoon at Farakka 1985-2010 (Flood Forecasting Cell, Irrigation Division, Malda, 2010)

The River Ganga changes its bank morphology and land utilization practices along river bank adjacent area during the monsoon period (from June to September). According to Singh et al. (2007), after the Farakka barrage construction (1971) flood frequency is rapidly increased. In 1998, extreme floods 
occurred that has caused the highest water level ever for the study area which was recorded at $25.40 \mathrm{~m}$ (District Human Development Report: Malda, West Bengal, 2007). For the study part of the Ganga River, it is observed that erosivity of water is affected by the amount of discharge and fluctuation in the river regime of the Ganga River which in turn induces bank erosion by various mechanisms especially by piping action (Rudra 2010; Thakur et al., 2011). Thus, in the Ganga and the Fulahar River, the danger level is $24.69 \mathrm{~m}$ to $27.43 \mathrm{~m}$, and the extreme danger level is $25.30 \mathrm{~m}$ to $28.35 \mathrm{~m}$ (Flood Forecasting Cell, Irrigation Division, Malda, 2010) (Fig. 10). At this time, the high discharge of water forcefully hits the river banks and the bank of the river to collapse due to the imbalanced pressure. This part of the Ganga River has possibly been changed due to the construction of the Farakka barrage that asserts exclusively to the continuous aggradations and sand and gravel bar formation. Sediment supply and its deposition under fluctuating discharge disturb the morphology of a river (Bandyopadhyay, 2014) and lead to entropy maximization that induces instability. Moreover, we have calculated charland (deposited inland bar) area of the study area which depicts that charland area has gradually increased during the study time period. During the last 47 years (1973-2020), the total charland accretion is $362.06 \mathrm{~km}^{2}$ and the annual charland accretion rate is $7.70 \mathrm{~km}^{2} / \mathrm{y}$ (Fig. 11). This huge sediment load in the monsoon period has a significant impact on channel instability in this study area. In case of the Ganga River, channel management through the construction of the Farakka barrage across the river played a significant role in a river channel change. Farakka barrage across the river affects morphology and the channel flow dynamics. Besides, it has invited unsolved and forced natural problems for surrounding people. So, we have tried to depict future vulnerable areas with river embankment conditions. This work will definitely assist to make policy framing purposes for future sustainable management.

Fig. 11. Charland area extension of the study area, (a) 1973, (b) 1987, (c) 1997, (d) 2007. (e) 2020.

\section{Conclusion}

This work has demonstrated the application and capability of earth observatory technology. It's generated a complete evaluation of spatial changes in river channel dynamics. During the last 47 years, the average erosion and accretion rate is $0.059 \mathrm{~km} / \mathrm{y}$ and $0.022 \mathrm{~km} / \mathrm{y}$ at the left bank and $0.026 \mathrm{~km} / \mathrm{y}$ and 0.046 at the right bank respectively. The multi-temporal data analysis reveals that the Ganga River has continuously changed its bankline positions from extensive erosion and accretion processes and modified its adjacent village area significantly especially towards the left bank. Uncontrolled erosion and accretion process in the vicinity of Farakka barrage has resulted in development of meanders and its migration towards Malda district, West Bengal (India) resulting in flooding, loss of life, agricultural lands and other properties on both the banks. The prediction result reveals that the very high vulnerable condition of 06 villages and 
BEHI score also very high. Moreover, REBVI scores have been significantly helping in understanding and identification vulnerable areas of embankment beaching. In this study, the DSAS based automated approach result and BEHI result both are same direction. This is validated that the DSAS employed as an alternative way that successfully and accurately measures and predicts geomorphic processes (future bankline positions and erosion-accretion) at an appropriate spatio-temporal scale. Among the various important factors, physiographic setting, tectonic activities, discharge fluctuation, sediment load, floods and massive human intervention in the form of the Farakka barrage across the Ganga River are the most significant factors for this dynamicity of the river. The level of accuracy is validated by the actual bankline positions (2020) with predicted bankline (2020) empirically. Besides, RMSE and statistics test are found useful to validate this work. Furthermore, it is evident that riverbank migration and land utilization will support to improve the river adjacent villages for restoration and management as well as uplift the socio-economic condition of the riparian peoples in the future. Therefore, the outcome of the predictions results could serve not only as spatial guidelines for monitoring future trends of channel

\section{References}

Ashwini, K., Pathan, S., \& Singh, A. 2020. Understanding planform dynamics of the Ganga River in eastern part of India. Spatial Information Research, 29(4), 507-518. doi: 10.1007/s41324-02000373-3

Ashraf, Muhammad, and Abdul Sattar Shakir. 2018. "Prediction of River Bank Erosion and Protection Works in A Reach of Chenab River, Pakistan". Arabian Journal of Geosciences 11 (7).doi:10.1007/s12517-018-3493-7.

Alberico, I., Amato, V., Aucelli, P. P. C., D’Argenio, B., Paola, G. Di, and Pappone, G. 2012. Historical shoreline change of the Sele Plain (Southern Italy): The 1870-2009 time window, J. Coastal Res., $28,1638-1647$.

Appeaning Addo, K.,Walkden, M., and Mills, J. P.2008. Detection, measurement and prediction of shoreline recession in Accra, Ghana, ISPRS J. Photogramm. Remote Sens., 63, 543-558.

Anders, F.J., Byrnes, M.R., 1991. Accuracy of shoreline change rates as determined from maps and aerial photographs. Shore and Beach, 59, 17-26.

Bera, B., S. Bhattacharjee, and C. Roy. 2019. "Estimating Stream Piracy in The Lower Ganga Plain of a Quaternary Geological Site in West Bengal, India Applying Sedimentological Bank Facies, Log and Geospatial Techniques". Current Science 117 (4): 662. doi:10.18520/cs/v117/i4/662-671. 
Bandyopadhyay, Shreya, Kapil Ghosh, and Sunil Kumar De. 2014. "A Proposed Method of Bank Erosion Vulnerability Zonation and Its Application on the River Haora, Tripura, India". Geomorphology 224: 111-121. doi:10.1016/j.geomorph.2014.07.018.

Chakrapani, G. J., V. Subramanian, R. J. Gibbs, and P. K. Jha. 1995. "Size Characteristics and Mineralogy of Suspended Sediments of The Ganges River, India". Environmental Geology 25 (3): 192-196. doi:10.1007/bf00768548.

Das, B. 2011. Stakeholders' perception in identification of river bank erosion hazard: a case study. Natural Hazards, 58(3), 905-928. doi: 10.1007/s11069-010-9698-Z

Dewan, Ashraf, Robert Corner, AshtySaleem, Md Masudur Rahman, Md Rafiqul Haider, Md Mostafizur Rahman, and Maminul H. Sarker. 2017. "Assessing Channel Changes of The Ganges-Padma River System in Bangladesh Using Landsat And Hydrological Data". Geomorphology 276: 257-279. doi:10.1016/j.geomorph.2016.10.017.

Dutta, P., 2011. Migration as Source of Risk-aversion Among the Environmental Eefugees: The Case of Women Displaced by Erosion of the River Ganga in the Malda District of West Bengal, India, Bielefeld: COMCAD.

de Bethune S, Muller F, \&Donnay J.P, 1998. Fusion of multispectral and panchromatic images by local mean and variance matching filtering techniques. Fusion of Earth Data, 28-30.

Esteves, L. S., Williams, J. J., Nock, A., and Lymbery, G.2009. Quantifying shoreline changes along the Sefton coast (UK) and the implications for research-informed coastal management, J. Coastal Res., $56,602-606$.

Ellison, J. C. and Zouh, I.2012. Vulnerability to climate change of mangroves: Assessment from Cameroon, Central Africa, Biology, 1, 617-638.

Fenster M., Dolan R., Elder J. 1993. - A new method for predicting shoreline positions from historical data. Journal of Coastal Research, 9: 147-171.

Guchhait, Sanat Kumar, Aznarul Islam, Sandipan Ghosh, Balai Chandra Das, and Nishith Kumar Maji. 2016. "Role of Hydrological Regime and Floodplain Sediments in Channel Instability of The Bhagirathi River, Ganga-Brahmaputra Delta, India". Physical Geography 37 (6): 476-510. doi:10.1080/02723646.2016.1230986.

Ghosh, Krishna Gopal, Swades Pal, and Sutapa Mukhopadhyay. 2016. "Validation of BANCS Model for Assessing Stream Bank Erosion Hazard Potential (SBEHP) in Bakreshwar River of Rarh Region, Eastern India". Modeling Earth Systems and Environment 2 (2).doi:10.1007/s40808-016-0172-0.

Hapke, C. J., Reid, D., and Richmond, B.2009. Rates and trends of coastal change in California and the regional behavior of the beach and cliff system, J. Coastal Res., 25, 603-615. 
Hai-Hoa, N., McAlpine, C., Pullar, D., Johansen, K., and Duke, N. C.2013. The relationship of spatialtemporal changes in fringe mangrove extent and adjacent land-use: Case study of Kien Giang coast, Vietnam, Ocean Coast. Manage., 76, 12-22, 2013.

Islam, A., Guchhait, S.K. 2017. "Analysing the influence of Farakka Barrage Project on channel dynamics and meander geometry of Bhagirathi river of West Bengal, India".Arab $J$ Geosci 10, 245. https://doi.org/10.1007/s12517-017-3004-2

Jana, Subrata. 2019. "An Automated Approach Estimation and Prediction of Riverbank Shifting for Flood-Prone Middle-Lower Course of The Subarnarekha River, India". International Journal of River Basin Management, 1-19. doi:10.1080/15715124.2019.1695259.

Kuleli, T., Guneroglu, A., Karsli, F., and Dihkan, M. 2011. Automatic detection of shoreline change on coastal Ramsar wetlands of Turkey, Ocean Eng., 38, 1141-1149.

Khan, Sana, Rajiv Sinha, Paul Whitehead, Sananda Sarkar, Li Jin, and Martyn N. Futter. 2018. "Flows and Sediment Dynamics in The Ganga River Under Present and Future Climate Scenarios". Hydrological Sciences Journal 63 (5): 763-782. doi:10.1080/02626667.2018.1447113.

Kankara, R.S., S. Chenthamil Selvan, Vipin J. Markose, B. Rajan, and S. Arockiaraj. 2015. "Estimation of Long- and Short-Term Shoreline Changes Along Andhra Pradesh Coast Using Remote Sensing and GIS Techniques". Procedia Engineering 116: 855-862. doi:10.1016/j.proeng.2015.08.374.

Langat, Philip Kibet, Lalit Kumar, and Richard Koech. 2018. "Understanding Water and Land Use Within Tanaand Athi River Basins in Kenya: Opportunities for Improvement". Sustainable Water Resources Management 5 (3): 977-987. doi:10.1007/s40899-018-0274-0.

Li R., Liu J., Felus Y. 2001. Spatial modelling and analysis for shoreline change and coastal erosion monitoring. Marine Geodesy 24: 1-12. doi: http://dx.doi.org/10.1080/01490410121502.

Mondal, M., \& Satpati, L. N. 2012. Morphodynamic setting and nature of bank erosion of the ichamati river in swarupnagar and baduria blocks , 24 Parganasz (N), West Bengal. Indian Journal of Spatial Science, 3(2), 35e43.

Mondal, J., \& Mandal, S. 2018. Monitoring changing course of the river Ganga and land-use dynamicity in Manikchak Diara of Malda district, West Bengal, India, using geospatial tools. Spatial Information Research, 26(6), 691-704. doi: 10.1007/s41324-018-0210-2

Majumdar, S., \& Mandal, S. 2020. Assessment of relationship of braiding intensities with stream power and bank erosion rate through Plan Form Index (PFI) method: a study on selected reaches of the upstream of Ganga river near Malda district, West Bengal, India. Sustainable Water Resources Management, 6(6). doi: 10.1007/s40899-020-00462-z 
Mukherjee, K., \& Pal, S. 2017. Channel migration zone mapping of the River Ganga in the Diara surrounding region of Eastern India. Environment, Development And Sustainability, 20(5), 21812203. doi: 10.1007/s10668-017-9984-y

Mukhopadhyay, Anirban, Sandip Mukherjee, Samadrita Mukherjee, Subhajit Ghosh, Sugata Hazra, and Debasish Mitra. 2012. "Automatic Shoreline Detection and Future Prediction: A Case Study on Puri Coast, Bay of Bengal, India". European Journal of Remote Sensing 45 (1): 201-213. doi:10.5721/eujrs20124519.

Mondal, M. Gouri, S. B and Pravart K.S., 2012. "Vulnerability Analysis of Embankment Breaching", International Journal of Geology, Earth and Environmental Sciences ISSN: 2277- 2081.

Natesan, U., Thulasiraman, N., Deepthi, K., and Kathiravan, K. 2013. Shoreline change analysis of Vedaranyam coast, Tamil Nadu, India, Environ. Monit. Assess., 185, 5099-5109.

Rahman, A. F., Dragoni, D., and El-Masri, B. 2011. Response of the Sundarbans coastline to sea level rise and decreased sediment flow: A remote sensing assessment, Remote Sens. Environ., 115, $3121-3128$.

Pal, R., \& Pani, P. 2019. Remote sensing and GIS-based analysis of evolving planform morphology of the middle-lower part of the Ganga River, India. The Egyptian Journal Of Remote Sensing And Space Science, 22(1), 1-10. doi: 10.1016/j.ejrs.2018.01.007

Raj, C., \& Singh, V. 2020. Assessment of planform changes of the Ganga River from Bhagalpur to Farakka during 1973-2019 using satellite imagery. ISH Journal Of Hydraulic Engineering, 1-11. doi: 10.1080/09715010.2020.1812123

Rudra, Kalyan. 2010. "Dynamics of The Ganga in West Bengal, India (1764-2007): Implications for Science-Policy Interaction". Quaternary $\quad$ International $227 \quad$ (2): 161-169. doi:10.1016/j.quaint.2009.10.043.

Rosgen, D.L., 2001 A stream channel stability assessment methodology, 7th Federal Interagency Sediment Conference, March 25-29, Reno, Nevada.

Rosgen, D. L., 2006. A watershed assessment for river stability and sediment supply (WARSSS). Wildland Hydrology Books. Fort Collins. Colorado.

Sarif, M., Siddiqui, L., Islam, M., Parveen, N., \& Saha, M. 2021. Evolution of river course and morphometric features of the River Ganga: A case study of up and downstream of Farakka Barrage. International Soil And Water Conservation Research,9(4), 578-590. doi: 10.1016/j.iswcr.2021.01.006

Sinha, Rajiv, and Santosh Ghosh. 2012. "Understanding Dynamics of Large Rivers Aided by Satellite Remote Sensing: A Case Study from Lower Ganga Plains, India". Geocarto International 27 (3): 207-219. doi:10.1080/10106049.2011.620180. 
524 Singh, Munendra, IndraBir Singh, and German Müller. 2007. "Sediment Characteristics and 525 Transportation Dynamics of The Ganga River". Geomorphology 86 (1-2): 144-175.

526

527

528

529

530

531

532

533

534

535

536

537

538

539

540

541

542

543

544

545

546

547

548

549 doi:10.1016/j.geomorph.2006.08.011.

Simpson, Aiden, Ian Turner, Eve Brantley, and Brian Helms. 2014. "Bank Erosion Hazard Index as An Indicator of Near-Bank Aquatic Habitat and Community Structure in A Southeastern Piedmont Stream". Ecological Indicators 43: 19-28. doi:10.1016/j.ecolind.2014.02.002.

Thakur, P., Laha, C., \& Aggarwal, S. 2011. River bank erosion hazard study of river Ganga, upstream of Farakka barrage using remote sensing and GIS. Natural Hazards, 61(3), 967-987. doi: $10.1007 / \mathrm{s} 11069-011-9944-\mathrm{Z}$

Thieler, E. R., \& Himmelstoss, E.A., Zichichi, J.L., and Ergul, Ayhan. 2009. Digital Shoreline Analysis System (DSAS) version 4.0 - An ArcGIS extension for calculating shoreline change: U.S. Geological Survey Open-File Report 2008-1278.

Wang, Bo, and Y. Jun Xu. 2018. "Dynamics of 30 Large Channel Bars in The Lower Mississippi River in Response to River Engineering From 1985 To 2015". Geomorphology 300: 31-44. doi:10.1016/j.geomorph.2017.09.041. 


\section{Figures}

\section{Figure 1}

Location map of the study area (A) India, (B) West Bengal, (C) The Ganga River floodplain with river buffer Mouza.

\section{Figure 2}

Conceptual framework of the methods used.

\section{Figure 3}

Different banklines (1973-2020) are positioned along the baseline. All transects are oriented at angle with the corresponding baselines. (A) Right bankline and (B) Lift bankline.

\section{Figure 4}

DSAS model-based prediction of riverbank erosion and deposition rate along transects during the different study periods, at the both banks. (a) Right bank and (b) Lift bank of 1973-1987; (c) Right bank and (d) Lift bank of 1987-1997; (e) Right bank and (f) Lift bank of 1997-2007; (g) Right bank and (h) Lift bank of 2007-2020; (i) Right bank and (j) Lift bank of 2000-2025; (k) Right bank and (I) Lift bank of 20252035; (m) Right bank and (n) Lift bank of 2035-2045.

\section{Figure 5}

DSAS model-based prediction of riverbank accretion-erosion rate during the study periods at the both banks. (a) Right bank and (b) Lift bank of 1973-1987; (c) Right bank and (d) Lift bank of 1987-1997; (e) Right bank and (f) Lift bank of 1997-2007; (g) Right bank and (h) Lift bank of 2007-2020; (i) Right bank and (j) Lift bank of 1973-2020; (k) Right bank and (I) Lift bank of 2020-2025; (m) Right bank and (n) Lift bank of 2025-2035; (o) Right bank and (p) Lift bank of 2035-2045.

\section{Figure 6}

Spatial pattern of bankline migration after prediction in the year 2020, 2025, 2035, and 2045. 


\section{Figure 7}

Spatial distributions of erosion and deposition area during the period (a) 1973-1987, (b) 1987-1997, (c) 1997-2007, (d) 2007-2020, (e) 2020-2025, (f) 2025-2035, and (g) 2035-2-45.

\section{Figure 8}

Sample Segment (location) specific mean BEHI ratings along the left bank of the Ganga River, (a) low BEHI score area (7.25) at Deonapur, (b) low BEHI score area (22.75) at Jagannathpur, (c) high BEHI score area (42.45) at Jot Bhabani, (d) high BEHI score area (43.95) at Gopalpur.

\section{Figure 9}

Sample Segment (location) specific mean REBVI ratings along the left bank of the Ganga River, (a) during the bank erosion time at PalgachhiMouza, (b) during the bank erosion time at Dharampur, (c) during the bank erosion time at Manikchak, (d) during the bank erosion time at Gupalpur, (e) during the bank erosion time at Sukhesna, (f) Above $90^{\circ}$ angel slope at Panchanandapur, (g) Soil different layer at Bagdukra, (h) Temporary embankment at Nayagram, (i) broken embankment at Jot Ananta.

\section{Figure 10}

River Flow Characteristics during the Monsoon at Farakka 1985-2010 (Flood Forecasting Cell, Irrigation Division, Malda, 2010)

\section{Figure 11}

Charland area extension of the study area, (a) 1973, (b) 1987, (c) 1997, (d) 2007. (e) 2020.

\section{Supplementary Files}

This is a list of supplementary files associated with this preprint. Click to download.

- Supplementarymaterial.doc 